\title{
LA HISTORIA (ECONÓMICA) INTERMINABLE DEL TIEMPO DE CERVANTES
}

\author{
JOAQUÍN OCAMPO SUÁREZ-VALDÉS \\ Universidad de Oviedo ${ }^{\mathrm{a}}$
}

\begin{abstract}
RESUMEN
De generación en generación, el Quijote, heraldo de las esencias patrias, ha sido devotamente releído y reinventado. Del mismo modo, Cervantes y su tiempo fueron recorridos hasta la extenuación por toda suerte de estudiosos dispuestos a arrancar del sepulcro del hidalgo manchego alguna clave explicativa del destino de España. Las páginas que siguen no se aplican a una lectura económica del texto. Desde la que hiciera Piernas Hurtado en 1874 hasta este mismo año, son demasiados los ensayos en tal dirección. Aquí se propone un recorrido alternativo que, partiendo de los doctores salmantinos y a través de los caminos del arbitrismo, de la Ilustración y de la historiografía económica liberal, agota su trayecto en «el tiempo de Pierre Vilar». Al final del viaje no debe desalentar constatar que «todo es según el color del cristal con que se mira»; los progresos ópticos, al corregir las distorsiones de las lentes, acaban por acercar los puntos de vista y suscitar así el acuerdo entre los observadores.
\end{abstract}

Palabras clave: Quijote, Cervantes, historiografía, decadencia

\footnotetext{
a Departamento de Economía, Facultad de Ciencias Económicas, Campus del Cristo, Avda. del Cristo, s/n, 33006, Oviedo. jocampo@uniovi.es
} 


\begin{abstract}
Don Quixote, herald of patriotic essences, has been devotedly read and reinvented generation after generation. Likewise, Cervantes and his time have been studied until exhaustion by all kinds of scholars prepared to snatch a key from the grave of the nobleman from La Mancha, which could explain the destiny of Spain. In the following pages, the text will not be interpreted from the point of view of economics. Since the works of Piernas Hurtado to this very year of the celebration of the centenary, a fair amount of essays have been produced from that perspective. An alternative analysis is proposed here which, starting with the School of Salamanca and going through Arbitrismo, Enlightenment and the liberal economic historiography, ends at «the time of Pierre Vilar». At the end of the journey one shouldn't be disappointed at verifying that «all depends on the colour of the glass you look through at this matter». The advances in optics have adjusted the distortions caused by faulty lenses and have hence brought different points of view closer together. Today there is considerable agreement amongst scholars.
\end{abstract}

Keywords: Don Quixote, Cervantes, historiography, decline.

JEL Classification: B30, N00

«Sancho, amigo, has de saber que yo nací en esta nuestra edad de hierro para resucitar en ella la de oro»

En 1925, Américo Castro (1980, p. 219) no hallaba en el Quijote datos que permitiesen deducir si «el autor escribía en vista del apogeo o decadencia» de España. Cincuenta años más tarde, J. A. Maravall (1976, p. 20) lo contradecía al sostener que Cervantes conocía la «penosa situación de la sociedad de la época», y añadía que, leído el Quijote como «revelación» del contraste entre una petrificada y utópica sociedad ideal y el incontestable avance del mundo moderno, el texto adquiere «un sentido transparente y total». El mismo criterio era compartido por H. Kamen en fechas recientes: frente al tópico de que el Quijote pretendía mostrar la «riqueza de la sociedad española del Siglo de Oro», no cabe sino esgrimir las propias palabras con que el hidalgo manchego se dirige a Sancho aludiendo a «estos nuestros detestables siglos» o a esta «depravada edad nuestra». Por eso, concluía Kamen (2005), «el libro se sitúa entre los que no dibujan un Siglo de Oro, sino más bien todo lo contrario». Hablando de aquella centuria áurea, otro hispanista, Bennassar (1983, p. 7), se sorprendía de que la expresión Siglo de Oro, de uso tan corriente en la literatura europea y americana, careciese en España de definición precisa: «Se advierte con gran sorpresa que los historiadores españoles evitan cuidadosamente» aquella fórmula. 
Sirva este preámbulo para advertir que apelamos a voces tan autorizadas para reclamar su protección a la hora de afrontar el camino, tan trillado, de analizar una etapa de nuestro pasado económico durante mucho tiempo elevada al panteón de las «esencias patrias». No se va a diseccionar el Quijote con vistas a su lectura económica. Desde Piernas Hurtado a Pierre Vilar, la obra de Cervantes ha contado con magistrales forenses. En estas páginas, con el norte puesto en informar deleitando, se propone una singladura por las llanuras castellanas a lomos de la historia de los hechos y de las doctrinas económicas. Para tal viaje no se pide al lector y al colega más alforja que la liviandad de su paciencia.

\section{DECLINACIÓN DE UNA REPÚBLICA DE HOMBRES ENCANTADOS (1500- 1700)}

«Desde que Dios creó el mundo no ha habido otro imperio en él tan dilatado como el de España, porque, desde que sale el sol hasta que vuelve a salir, está alumbrando tierras de esta gran monarquía.»

F. Ugarte (1655)

La figura del cronista real, institucionalizada desde 1450, no dio de sí más que cronologías, genealogías o relatos providencialistas en los que las laudes hispaniae constituían el telón de fondo sobre el que los Ocampo, Morales, Garibay o Sandoval justificaban su condición de historiadores a sueldo de la Corona. Acaso por ello, el Consejo de Castilla les hubo de incitar «no solo a escribir de las vidas de reyes y de guerras, sino también de otras muchas cosas tocantes a sus súbditos» ${ }^{1}$. Los arbitristas no gozaron de mejor predicamento: «Riéronse todos del arbitrio y del arbitrante, y él también se rio de sus disparates». Colmeiro completará la faena iniciada por el esperpento cervantino del Coloquio de los perros (1613) al reducir el arbitrismo «al arte de sangrar la vena de la común riqueza», pero, como bien hiciera notar J. Vilar, la ambigüedad de la sátira cervantina radica en que el desprestigio del vendedor de humo se hace extensivo a toda la sociedad, dispuesta a adquirir tan volátil mercadería².

La rehabilitación del arbitrista llegó con la reedición por Campomanes (1775, pp. iv-xi) de aquellos escritores políticos del Seiscientos en cuyos «discursos, más políticos que morales», se advertía «un diseño de las causas» de la decadencia. Dos siglos más tarde, E. J. Hamilton (1948, p. 205) sería más radical en su puesta al día: los mercantilistas, «poco inclinados a la especulación» y ante el «deplorable retroceso» de su tiempo,

\footnotetext{
${ }^{1}$ García Cárcel (2004, pp. 14-42) y Kagan (2002, p. 123).

${ }^{2}$ Colmeiro (1965, p. 397) y Vilar Berrogaín (1973, pp. 263-264 y 288-293).
} 
«formularon valiosos preceptos, en gran parte o totalmente disociados de la acumulación de metales preciosos pero conducentes a la potencia y al bienestar económicos. Con visión profética, denunciaron la mayor parte de los males que conducían a España a la ruina [...]. La historia consigna pocos ejemplos bien de un tal acertado diagnóstico, bien de una tan terrible desatención de acertados consejos por parte de los hombres de Estado.»

En 1954, y pese a sus dudas respecto a las tesis de Larraz, Schumpeter (p. 133) elogiaba el alto nivel de las aportaciones, tanto a «la economía pura (teoría del valor) como a la aplicada», de la escolástica española del siglo xvi; y ello «por la facilidad con que la economía de los doctores absorbió todos los fenómenos del capitalismo naciente». La «economía vulgar» que destilaban las obras de panfletistas y proyectistas, «sin duda muy interesante para la historia económica» (pp. 203-207), marcaba la transición entre el internacionalismo cultural medieval y la emergencia de los estados nacionales. Ya en fechas más recientes, Perrotta (1993) ha apuntado la posibilidad de que el descrédito social del arbitrismo pudiera ser «interesado», en la medida en que, con el mismo, se trataba de estigmatizar una literatura que denunciaba los vínculos entre señorialización, opresión política y pobreza.

\subsection{La edad dorada (1500-1550): la hora de la economía moral}

El nacimiento de Cervantes (1547) venía a coincidir con el final de «los años de optimismo» de la economía española ${ }^{3}$. Siguiendo los ciclos coyunturales acotados por Chaunu, P. Vilar (1969, p. 218) se refería a esta etapa como «tiempo de satisfacción de los mercaderes y de inquietud de los consumidores». La magnitud de los cambios sobrevenidos en la primera mitad del Seiscientos será terreno abonado donde florezca una nutrida oferta de valoraciones por parte de tres críticos de excepción: los teólogos y juristas, depositarios del tomismo y de la ortodoxia moral; las Cortes, portavoces de comerciantes, consumidores y fabricantes de las ciudades castellanas, y, por último, los consejeros de Estado y escritores políticos.

La subida de precios, el bullicio de los negocios y el trajín de los cambios en ferias, así como la promoción social de nuevos grupos sociales, exigieron a los doctores, en palabras de García Sanz (1999), «cohonestar acumulación de capital y moral católica». Por lo mismo, la literatura económica emanada de los manuales de confesores surgía como «subproducto de un programa investigador moral» ${ }^{4}$.

\footnotetext{
${ }^{3}$ Grice-Hutchinson (1978), p. 165.

${ }^{4}$ M. J. González (1993), pp. 21-39.
} 
El valor analítico de este último ha sido doblemente ponderado. En primer lugar, desde la óptica de la economía monetaria se nos recuerda cómo el «doctor navarro», en su Comentario resolutorio de cambios (1556), adelantaba en doce años respecto a La Response de Bodin la teoría cuantitativa del dinero. Por su lado, la Summa de tratos y contratos (1571), de Tomás de Mercado, al indagar sobre la relación entre las fluctuaciones de los tipos de cambio de las divisas y los niveles nacionales de precios, albergaba el embrión de la futura teoría de la paridad del poder de compra de las monedas. Finalmente, señala Baeck (1998), la escuela de Salamanca, al adaptar sus reflexiones a una economía que dejaba de ser estacionaria y en la que el dinero, de medio de cambio estéril, se convertía en instrumentum persistens lucri, pudo realizar precisiones sobre la teoría del interés y del beneficio. Comenzaban así a conmoverse los pilares en los que descansaban las tesis sobre la usura y el precio justo y, en los textos, comenzaba a entreverse la presencia de los mecanismos autónomos del mercado. En segundo lugar, y desde una perspectiva epistemológica, Gómez Camacho (1999) ha destacado la contribución de la Escuela a la fundación de la economía científica a través del despliegue doctrinal a que dieron lugar las controversias sobre el pauperismo, la propiedad privada, la fiscalidad o la formación de los precios en los mercados del trigo y de la lana.

\subsection{0-1560: «Para que no salgan dineros de España»}

Coincidiendo con el agotamiento de las remesas de oro y a la espera de que las técnicas de amalgama diesen frutos en Potosí y Zacatecas, el ciclo de las «prosperidades fáciles» deja paso a la «gran recesión», por utilizar términos acuñados por Chaunu. Para los años 1547-1567, P. Vilar (1969, p. 158) habla de toma de conciencia acerca «de los peligros del parasitismo colonial», del alza de precios y del déficit comercial. Por su parte, Nadal (2001, pp. 151-160) identifica este ciclo como el del tránsito de la expansión carolina a la crisis filipina; durante el mismo, la crisis financiera y la elevación de tipos de interés, al penalizar las iniciativas empresariales, acabará por consagrar las figuras del rentista y del terrazguero.

Llegaba la hora de los escritores políticos y del empirismo: la balanza comercial y las políticas económicas desplazan a las sutilezas de los doctores como foco de atención. 1558 es el año del Memorial de Luis Ortiz «para que no salgan dineros del Reyno» o, como quisiera E. Lluch, «Cómo quitar de España toda la ociosidad e introducir el trabajo». El texto será saludado por Hamilton como visión «notablemente lúcida y consistente» de la balanza comercial, y por GriceHutchinson y Perrotta como obra pionera del mercantilismo europeo. El hecho de que en seis capítulos del Memorial se hiciese referencia a la salida de plata llevó a tildarlo de bullonista cuando, como ha señalado Larraz, era la exposición de un 
amplio programa industrialista concebido a partir de la consideración de la divergencia entre las economías española y europea ${ }^{5}$.

\subsection{0-1600. De salvar almas a salvar a España: la hora del mercado}

La puesta en explotación del cerro de la plata (Potosí) mediante el sistema de patio estimuló de nuevo las entradas de plata. Los precios retoman su marcha ascendente y, sin embargo, en las Cortes de 1594 saltará la alarma: «El Reino está diezmado». Otra vez los teólogos tomarán la pluma: Giginta y Pérez de Herrera, para tratar del pauperismo; Luis de Molina, para fijar las posiciones de la escuela con relación a precios, cambios y préstamos; Pons, Valle de la Cerda y Marina, para referirse a los erarios públicos o a los límites de la acción tributaria.

Paradójicamente, los años de la plata serán también, como los definió Carande, los «años aflictivos» de la Hacienda: las incautaciones practicadas sobre los cargamentos de los particulares a cambio de juros retrasan los pagos en las ferias y amedrentan al que Ruiz Martín llamó «capitalismo cosmopolita». A la petrificación de alcabalas en tiempos de Carlos v le seguirá la «ofensiva fiscal» filipina: incremento de encabezamientos de alcabalas, creación de nuevas figuras impositivas -millones, estancos, excusado...-, expolio de bienes municipales, venta de oficios e hidalguías...-. Es en tal tesitura en la que la braudeliana «deserción burguesa» ha merecido serias rectificaciones ${ }^{6}$. Si a las medidas de las Cortes de 1548 y 1552 autorizando la importación de paños extranjeros puede imputárseles la «liquidación de negocios e ingreso en la legión de rentistas» por parte de los industriales ${ }^{7}$, otro tanto cabría decir de la venta de propios: la de inducir a los capitales a buscar refugio en las rentas de la tierra. De esta guisa lo expresaba Tomás de Mercado (1977, p. 63), en 1517, refiriéndose a los mercaderes que «con apetito de nobleza e hidalguía han tratado de subir fundando buenos mayorazgos».

\subsection{0-1616: la hora de la declinación y de los arbitrios}

«Hacía falta algo más que un cambio de rumbo para arreglar los males de España. ¿Quizá un cambio de barco? En todo caso, a la deriva, aquella nao seguiría navegando. El barco navegaría quemando sus propias maderas.» ${ }^{8}$

Pese a las arremetidas secularizadoras, a punto de sucumbir la recta razón frente a la razón científica, el internacionalismo tomista aún se haría escuchar. Nadie como

\footnotetext{
${ }^{5}$ Larraz (1943, pp. 107-119) y Perdices de Blas (1996).

${ }^{6}$ Yun (2002, pp. 51-84, y 2004, pp. 428-455) y Marcos Martín (2000, pp. 421-453).

7 Nadal (2001), p. 158.

${ }^{8}$ B. Yun (2004), p. 576.
} 
Mariana, el ilustre extremista, reflejará aquellos críticos años. Al contractualismo liberal de De rege (1598) le sucederá, en De monetae mutatione (1609), la radical descalificación de quien «sustrae la propiedad de los particulares» y «deja exhausto al pueblo exigiendo casi a diario nuevos tributos», pues no otra cosa que un oneroso impuesto sobre las haciendas particulares eran las alteraciones monetarias que divorciaban precio legal y natural ${ }^{9}$. Junto a los teólogos, una copiosa legión de tratadistas políticos y de reformadores sociales no iba a tardar en hacerse eco y dar cuenta escrita de la decadencia. Señala Martín Rodríguez (1999, pp. 359-402) que entre 1575 y 1605 se editaron más de un centenar de memoriales y tratados monográficos sobre la declinación y los males de España. Tres eran las aproximaciones sectoriales dominantes con que se abordaban ambas cuestiones: la sociológica, la institucional y la financiera o hacendística.

La crítica social levantaba acta de los elementos desvertebradores, tanto desde la perspectiva demográfica -celibato, epidemias, levas, emigración-como desde la económica y moral -picaresca, bandolerismo, rentismo, deshonra legal del trabajo, lujo...-. El hispanista B. Bennassar (1983, p. 172), refiriéndose a este punto, dejó escrito que «en la historia del mundo pocas sociedades han acumulado tantas desigualdades en unos espacios tan restringidos como la España del Siglo de Oro». En la aproximación institucional se enfatizarán las desigualdades que el orden jurídico imponía a la creación de riqueza. Las dianas más frecuentes se dirigían a los límites al mercado de tierras y arriendos impuestos por vínculos, censos, fideicomisos y amortizaciones. Saavedra Fajardo hacía coincidir edad dorada con prosperidad agraria: «con los frutos de la tierra se sustentó España, tan rica en los siglos pasados», pero en tiempos de Fernández de Navarrete la tierra se había convertido en objeto de pura especulación y en medio de «acaballerar la gente plebeya» ${ }^{10}$.

El «desempeño de la Hacienda» ocupará un lugar central en la agenda reformadora, y el propio rey Felipe III ordenaría en 1618 al Consejo de Hacienda una gran consulta acerca de «la conservación de esta Corona, tan necesitada de remedios por la falta de Hacienda que hay». El Consejo, tras constatar que, en efecto, esta última se hallaba «consumida y empeñada», lamentaba tanto los excesos de la carga tributaria como la asimetría fiscal entre Castilla y otros reinos «muy poblados, ricos y descansados». Fortalecer la Hacienda sin aniquilar a las clases medias parecía una contradicción irresoluble para un mercantilismo que concebía la riqueza como dada y, por lo mismo, en términos excluyentes. Saavedra Fajardo acertó a expresar así la paradoja fiscal: «Los brazos de las repúblicas son las ar-

${ }^{9}$ Cfr. Gómez Camacho (1998, pp. 309-313), Rothbard (1999, pp. 144-165) y Mateo del Peral (1977, pp. 381-383).

${ }^{10}$ Citas, en Saavedra Fajardo (1947, «Empresa LXIX», pp. 183-193) y Domínguez Ortiz (2000, p. 792). 
mas. No puede haber paz sin armas, ni armas sin sueldos, ni sueldos sin tributos» ${ }^{11}$.

De entre los economistas políticos, Campomanes supo apreciar a los que trataron de fundar sus opiniones «en hechos y datos, en el producto de las cosechas, en el verdadero vecindario, en el catálogo de los precios». La rehabilitación del arbitrismo, desde Hamilton o Iparaguirre a Perrota, Baeck o Perdices de Blas, ha destacado en él la voluntad de formular, a partir de la economía aplicada, una teoría explicativa del atraso económico español y, sobre la misma, de fundar una política de desarrollo equilibrado, empeño nada extraño si se considera que España se había convertido en arsenal empírico y banco de pruebas para buena parte de la literatura económica europea del momento. Pese a la heterogeneidad de corrientes, el mercantilismo español partía en sus análisis de un triple supuesto. En primer lugar, el sentimiento compartido de que existía una «declinación», tanto en términos absolutos, es decir, con relación al pasado económico nacional, como relativos, es decir, respecto a las economías atlánticas o «naciones industriosas» del entorno. En segundo lugar, se admitía con unanimidad que la decadencia no era un fenómeno del Seiscientos, sino que se superponía al hecho imperial y colonial. Frente al tópico -acuñado por la historiografía francesa de la Ilustraciónde una decadencia española imputable exclusivamente a los Austrias, Kamen enfatizaba cómo el arbitrismo español -a diferencia de lo propuesto por Hamilton y sus seguidores-, lejos de asociar grandeza y prosperidad hispánicas con imperio, verá en este último la raíz de los males patrios ${ }^{12}$. La formulación de un «cuasisistema» explicativo de la crisis conforma el tercer supuesto del arbitrismo español. Moncada apelaba a una «ciencia conservativa» para evitar el riesgo en que incurre cualquier reino que se «gobierna por sucesos». De ahí su actitud crítica frente a «las causas que comúnmente se dan» como explicación de la decadencia, y también su interés por «fechar con precisión», por hallar tendencias sobre las que sustentar explicaciones firmes ${ }^{13}$. Sobre tales premisas se irá construyendo un acervo doctrinal del que se han valorado el interés por la cuantificación, la asimilación entre riqueza y población/empleo, el industrialismo activo del llamado grupo de Toledo, y una redefinición del papel de Estado en la economía. Desde Heckscher viene siendo lugar común identificar mercantilismo con sistema de poder. En ningún momento las propuestas sobre erarios o en materia de contribuciones llegaron a cuestionar la necesidad de fortalecer las rentas reales. Tal evidencia no debe empañar otras que confirman la voluntad de reconciliar interés propio y fortaleza de la monarquía. Tesis como las que anuncian que de «la gente y negocios

${ }^{11}$ Citas, en Fernández de Navarrete (1947, pp. 451-456) y Saavedra Fajardo (1947, pp. 184-188). Vid. Sureda Carrión (1999, pp. 523-544).

${ }^{12}$ Cfr. Kamen (1985), Elliot (1961 y 1977) y Maravall (1984).

${ }^{13}$ Cfr. Moncada (1974, p. 229) y J. Vilar (1974 y 1999). 
resultan las rentas reales» o que «la potencia es efecto de las riquezas, y las riquezas son efecto de las artes» son, tomadas al azar entre otras análogas, expresiones con las que Moncada y Martínez de Mata afirmaban el equilibrio que debe presidir las relaciones entre el poder del Estado y la «felicidad pública» ${ }^{14}$.

Los discursos y memoriales de Mata y Osorio sirven de puente entre el reformismo mercantilista y el proyectismo de la primera mitad del Setecientos. La obra de Mata, elevada por Schumpeter al altar de los sistemas presmithianos, servirá para legar a la economía civil de la Ilustración tres dimensiones de la decadencia. Primera, «que en tiempos de los señores Reyes Católicos estuvo España rica y bien poblada» o, lo que es lo mismo: «Se prueba cómo, por haber librado España sus fuerzas más en las riquezas de las Indias que en las artes, con que las pudiera haber conservado, las ha perdido». En segundo lugar, el interés por recoger información cuantitativa va unido en ambos autores a un agudo análisis social sobre los procesos de refeudalización y «deserción burguesa»: «Los mercaderes de lonja se han hecho señores y pueden cosechar vasallos», que diría Mata. Finalmente, ya se hace presente en sus textos la transición hacia una economía política que eleva la «riqueza de los vasallos» a prioridad política: «Los vasallos son quienes rinden los tributos, el Príncipe debe conservar las ganancias e intereses que tiene cada uno en sus tratos, artes y rentas con suma atención» ${ }^{15}$.

\section{LECTURAS ILUSTRADAS DE LA DECADENCIA}

\section{1. «Convendría que la historia se escribiese de distinto modo»}

Se refería Forner a la necesidad de depurar fuentes, de incorporar la idea de progreso y de sustituir la causalidad vertical o teológica por la mecánica. Las referencias a los doctos economistas del grupo de Toledo, y a los Raynal, Mably, Diderot, Voltaire o Robertson, iban unidas a la exigencia de un «diseño» de la historia que incluyese los intereses políticos y económicos: a España «le importaba mucho» una historia de los Austrias por cuanto sus cronistas han sido «más bien abogados de sus abusos que relatores imparciales». Si, bajo los Reyes Católicos, España asistió a «la destrucción del poder feudal» y se hizo «culta, rica, industriosa y respetada en todo el occidente», tanto más urgente resultaba explicar «cómo contribuimos nosotros a nuestro precipicio por no querer ir a la par con las demás naciones en los progresos del comercio, de la marina y de las ciencias». No bastaba, pues, con apelar a lo que Masdeu llamaba «complexión natu-

\footnotetext{
${ }^{14}$ Una síntesis, en Perdices de Blas y J. Reeder (1997) y Argemí (2004). Citas, en Moncada (1974, Discurso IV, pp. 157-158) y en Martínez de Mata (1971, pp. 144-145).

${ }^{15}$ Cfr. Martínez de Mata (1971), Discursos VIII, p. 189; III, p. 127, y IV, p. 136.
} 
ral» del país ${ }^{16}$, y, sin embargo, tal apelación, junto a los tópicos antiaustracistas o los relativos a la divergencia con la Europa próspera y protestante, serán recurrentes. Para botón de muestra, la seguridad con que Cadalso condensaba esta última en las Cartas marruecas (1773): «Bien sé yo que desde el siglo Xvi hemos perdido los españoles el terreno que algunas otras naciones han ganado».

Pero, más allá de las sentencias fáciles, Feijoo, declarado admirador del «sutilísimo Newton», de Bacon y Locke, reconocía «las dificultades que hay en ejercer dignamente la profesión de historiador». Tras el «gloriosísimo y feliz» reinado de los Reyes Católicos y al escribir «el descuido de España, lloro porque el descuido de España me duele», iniciaba lo que Maravall designaría como una corriente de crítica nacional. La dedicatoria al industrial Goyeneche del tercer volumen de su Teatro crítico, de 1729 (1991), era un reconocimiento a quienes luchaban por contener la postración fabril española.

Frente a la voluntad divulgadora de Feijoo, será Mayans quien enarbole la bandera del rigor metodológico: no se puede «escribir ajustándose a la verdad sin tener los documentos y memorias necesarias, porque la historia no es la de las cosas meramente posibles, sino de las verdaderamente sucedidas» ${ }^{17}$. Además de sus valiosas críticas a las leyes sobre mayorazgos y vinculaciones, corresponde a Mayans, con su Vida de Miguel de Cervantes Saavedra, de 1738, el mérito de haber iniciado la saga de estudios cervantinos, mérito tanto mayor, como señalara Mestre, si se considera que ni Luzán citaba el Quijote ni Feijoo lo incluía en su «Glorias de España», de 1730.

La pasión ilustrada por la buena historia late y recorre las páginas de Campomanes, Capmany o Jovellanos. El primero, además de su temprana traducción de Davenant, en 1759, o de la reedición de Mata y Osorio, convertirá las sociedades económicas en verdaderas antorchas de la historia económica: «Cotejar el valor de las cosechas e industrias, compararlas de un año a otro, medir el valor de la población» o «comprar libros tocantes a la economía política» serán algunas de las funciones estatutarias que les encomendará. Jovellanos, en el discurso de su recepción en la Real Academia de la Historia, apelaba a la necesidad de una «historia civil que explique nuestras glorias y nuestras miserias». Capmany rechazaba abiertamente a aquellos sedicentes historiadores que, «bien fuese por pereza de consultar archivos o ya por ignorancia, no mostraron la menor curiosidad de ilustrar la parte económica» ${ }^{18}$.

${ }^{16}$ Cfr. Fontana (1982, pp. 58-77), Maravall (1991), Jover (1994). Citas, en Forner (1973, pp. 151-152, 156, 160 y 171-172) y Masdeu (1982, cit. en Catalán).

${ }^{17}$ Cfr. Feijoo (1991, tomo II, Discurso XV). Sobre Mayans, véanse Mestre (1970, p. 77) y Cervera Ferri (2003, pp. 48-64).

${ }^{18}$ Cfr. Rodríguez Campomanes (1975, pp. 103-118), Jovellanos (1952, tomo XLVI, pp. 288-298) y Capmany (1961, p. 8). 


\subsection{La decadencia desde la economía civil: divergencia con las naciones indus- triosas europeas}

Señalaba recientemente Gonzalo Anes (2004, pp. 53-63) cómo los escritores del XVIIII, «aun cuando reflexionaron» sobre la centuria anterior, «tendieron a pintar con negros colores» el panorama económico. Es cierto; la citada «crítica nacional» o «dolor de España», en terminología de Maravall, se reitera entre los proyectistas: «Escribo de España lo que no quisiera escribir», dirá Campillo en España despierta, de 1742. En la «Aprobación» a la Theórica, de 1724 (1968), se previene al lector de que la obra de Uztáriz expone «las grandes miserias que afligen a España», y en los Apuntes sobre el bien y el mal de España, de 1759 (1988), Gándara advertía de que «dos siglos ha que está bajando España porque dos siglos ha que retiró Dios el don de gobierno». No obstante, hubo algo más que lamentos.

En primer lugar, hay un claro interés en documentar el cambio de coyuntura. Gándara situaba la inflexión en torno a 1552, coincidiendo con la guerra de Flandes. Campillo, sin precisar, sitúa la brecha en el siglo XVI, mientras que el XVII, que «para otras naciones fue el siglo de oro, de la luces, de los buenos establecimientos y de prosperidades, fue para España siglo de desguace». Campomanes hará una lectura más económica del ciclo: «Hasta el fin del reinado de Felipe II, la nación no recibía manufacturas extranjeras; antes las extraía». Arriquíbar apuntaba a las llegadas de oro y plata, que aumentaron el valor «de los frutos, manufacturas, gajes y salarios» y a una presión fiscal extenuante, que «se echó sobre la parte inferior de los trabajadores, que son la riqueza productiva», como determinantes de la inversión de tal ciclo ${ }^{19}$.

En segundo lugar, la mayor disponibilidad de información estadística, el instrumental analítico proporcionado por la emergente economía política y el propio «revisionismo» borbónico excitaron la búsqueda de modelos explicativos coherentes de la decadencia. El primer paso consistió en la valoración de la información legada por el arbitrismo. Uztáriz, al analizar la balanza de comercio, insistirá en la necesidad de atenerse «a la certidumbre de los hechos». Ulloa, más crítico, mantenía que, si los economistas del Seiscientos «conocieron de dónde venía el daño de nuestras fábricas, lo cierto es que lo callaron, porque ni en los memoriales antiguos ni en los modernos se explica». Campomanes referirá también que el «defecto común y trascendental» de aquéllos radicaba en «la inexactitud de los hechos y datos en que fundan sus opiniones».

Más elaborado, el juicio de Jovellanos insistirá en que, aun cuando los «antiguos economistas» se «elevaron al origen de la decadencia» depositando en sus

${ }^{19}$ Cfr. Gándara (1988, pp. 73-74), Campillo (1993, pp. 56 y 67) y Rodríguez Campomanes (1775, p. xxxvii). Arriquíbar (1987, pp. 230-232). 
obras «una increíble copia de hechos», resultaban «inconstantes en sus principios», pues cada uno «formaba su sistema particular»; de ahí que su doctrina resultase «vacilante en sus principios, absurda en su consecuencias y equivocada en sus cálculos» ${ }^{20}$.

¿Cuál era entonces el diagnóstico de la decadencia? Prescindiendo de quienes, desde Amor de Soria a Foronda o Martínez Marina, se habían centrado en una lectura política de aquélla, es necesario subrayar la afinidad de principios compartidos por quienes pretendían una explicación económica. El primero, relativo a un voluntarismo científico desde cuya atalaya se depositará una desmesurada confianza -casi religiosa en el Elogio jovellanista- en la economía como panacea a los males u obstáculos al crecimiento económico. Por lo mismo, nadie dudará en vincular decadencia con desconocimiento de las luces y principios de la economía civil. Romá (1989, p. 2) lo expresaba de este tenor en 1768: «Aunque las costumbres y los acasos contribuyan a la prosperidad o a la decadencia del Estado, la ciencia del gobierno enseña a enmendarlos».

El segundo principio se plasma en la voluntad de ordenar y reducir a sistema la inabarcable casuística de los males. Ese afán de alcanzar una explicación de síntesis aparece claramente formulado en Uztáriz: «Es evidente que no puede haber población grande, ni abundancia, sin el auxilio de un comercio grande y útil», y «no puede haber comercio grande y útil sin la concurrencia de muchas y buenas manufacturas». El fundamento de esta tesis lo obtiene a partir de un ejercicio de historia económica comparada que le lleva a examinar los sistemas arancelarios de las potencias atlánticas, en las que descubrirá la «nueva política». Esta última será la piedra angular de todas las explicaciones de la decadencia. Como dirá Gándara, «Europa ha mudado de aspecto», ya que «todas las potencias han tomado el comercio por el objeto primero de sus desvelos; antiguamente se pensaba de otra manera, todo el objeto era extender mucho las conquistas».

Sería Campomanes, con el refuerzo doctrinal del mercantilismo liberal inglés, quien elevase a mayor altura explicativa el análisis de la decadencia. En la «Dedicatoria» de sus Reflexiones, quien había acuñado la expresión revolución mercantil para referirse al desempeño económico británico hacía notar que la paradoja del fracaso de una potencia colonial como España no podía explicarse «por las reglas actuales» o las «hasta aquí observadas». Esa paradoja, detectada por Mun, Huet, Monstesquieu, Cantillon o Adam Smith, entre otros, se acabará convirtiendo en un tópico ilustrativo de las dificultades que acompañaban la transición del capitalismo mercantil de las «potencias comerciantes» al industrial ${ }^{21}$. Indudablemente, el examen de la performance española a partir del modelo de explotación colonial

\footnotetext{
${ }^{20}$ Uztáriz (1968, capítulo XVIII, p. 39), Ulloa (1992, pp. 14-15) y Jovellanos (2000, p. 489).

${ }^{21}$ Llombart (1988).
} 
como núcleo explicativo y de la balanza mercantil como variable básica no fue el único diagnóstico suministrado por los estudiosos. Bernardo Ward, en su conocido Proyecto económico, de 1762, y Dámaso Generés, en las Reflexiones, de 1783, enfatizaban la superioridad de las manufacturas «bastas» británicas y de su sistema fabril descentralizado como una de las claves de su liderazgo económico; Jovellanos, en el Informe sobre el libre ejercicio de las artes, de 1785, y en el Informe de ley agraria, de 1795, otorgaba prioridad a los obstáculos institucionales como estimulantes del propio interés e incentivadores del crecimiento económico. Pero en uno u otro caso los argumentos acababan volviendo al comercio y a la balanza mercantil como escaparate o exponente del éxito de las «naciones industriosas», siempre evaluado a partir de la competitividad exterior de sus economías.

\section{LA DECADENCIA, VISTA DESDE EL SIGLO DEL LIBERALISMO}

«Cuando se reúnen unos cuantos españoles sensibilizados por la miseria ideal de su pasado, la sordidez de su presente y la acre hostilidad de su porvenir, desciende entre ellos don Quijote.»

Ortega y Gasset (1916)

Sirva este texto para ilustrar la proliferación de una vasta literatura, a menudo francamente indigesta, que, ya con ocasión de los debates de las Cortes de Cádiz, ya desde las páginas de El Censor o del Semanario Patriótico, ya coincidiendo con el repunte del regionalismo, ya con las polémicas finiseculares sobre la ciencia española, el casticismo o la regeneración, convertían a la Castilla imperial, al Siglo de Oro y al Quijote en heraldo y norte de toda suerte de ensayos sobre el dolor de España. Sainz Rodríguez (1924), Velarde (1961), Tuñón de Lara (1973) y Abellán (1989), entre otros, han sistematizado juiciosamente esas lecturas de España.

Aun tratándose de ensayos políticos, filosóficos o de escritos de lamentación, la economía como telón de fondo nunca dejaba de estar presente. Joaquín Costa contraponía al «Sancho británico» un Quijote español mantenedor «perenne de esa caballería espiritual que hace que la tierra sea algo más que un mercado». También el Ideario (1964) de Ganivet, de 1897, o Los males de la patria (1989) de Mallada, de 1890, aparecen serpenteados de alusiones a un imperio por encima de nuestras posibilidades; Almirall, por su parte, contraponía a John Bull el Quijote como arquetipo sociológico de la cultura y economía castellanas ${ }^{22}$.

${ }^{22}$ Costa (1981, p. 68), Fernández Clemente (2001), Ganivet (1897, p. 67), Mallada (1964, pp. 68-69) y Almirall (1979, pp. 30-41). 
En medio de tanto antiaustracismo, no deja de llamar la atención la soledad, tantas veces malinterpretada y manipulada, de Menéndez y Pelayo. Reconociendo la «lamentable decadencia» del comercio e industria y la ausencia de una «clase media propiamente dicha», se negaba a aceptar que fuesen los Augsburgo la explicación última de los males patrios. Tras recordar que fue la casa de Borbón «quien verdaderamente mató las tradiciones forales», concluía sosteniendo, a finales del siglo xix, que la España del xviI había sucumbido en su esfuerzo por «salvar a la Europa latina de la nueva invasión de los bárbaros septentrionales»²

\subsection{Historiografía liberal: la culpa fue de los Austrias}

«No hay nada más espantoso, más abominable, que aquel gran imperio español, un sudario que se extendía sobre el planeta»

E. Castelar

La Historia de Mariana seguirá reeditándose durante toda la primera mitad del siglo XI, y todavía en 1854, Pi y Margall prologaba la edición de la Biblioteca de Autores Españoles. No obstante, la insuficiencia de ofertas editoriales obligaba a recurrir a traducciones extranjeras a la vez que potenciaba las primeras historias de la civilización española -la de E. de Tapia, de 1840; la de F. Gonzalo Morón, 1841-. Estas últimas, a partir de la lectura de Vico, Voltaire, Hegel o Guizot, permitían ampliar la perspectiva analítica de los estudios históricos: los hechos de armas daban paso al protagonismo de las instituciones, del comercio y del progreso material. El terreno estaba preparado para la llegada de los treinta tomos de la Historia general de España (1850-1867), de Modesto Lafuente, la historia de España por antonomasia, la historia de las clases medias ilustradas del Sexenio y de la Restauración, cuyos volúmenes constituirán el blasón indispensable del mobiliario de salones y despachos respetables ${ }^{24}$.

Desde esta nueva memoria en versión liberal del pasado, la explicación de la decadencia no aporta sustanciales novedades respecto a las interpretaciones de Ferrer del Río o Colmeiro. Por lo mismo, en Lafuente podrán releerse tópicos y lugares comunes del arbitrismo y de la Ilustración, como los relativos «a la ignorancia de los verdaderos principios de la economía» o a un pasado medieval que inhabilitaba para el crecimiento económico a un pueblo más apto para el manejo de la espada que del $\operatorname{arado}^{25}$.

\footnotetext{
${ }^{23}$ Menéndez y Pelayo (1987), V, pp. 388-394.

${ }^{24}$ Cfr. López-Vera (2004, pp. 195-295) y Jover (1984, pp. 358-374).

${ }^{25}$ Lafuente (1877-1882, II, pp. 433 y ss., y III, p. 194).
} 
En 1876, con voluntad de institucionalizar y profesionalizar los estudios históricos, salía el primer número del Boletín de la Real Academia de la Historia. Poco después, con Cánovas al frente de la Academia, nacía, con pretensión de historia autorizada, el proyecto de una Historia general que nunca llegaría a rematarse. El propio Cánovas publicaría en 1854 una Historia de la decadencia de España entre los reinados de Felipe III y Carlos II, materia sobre la que, con matizaciones, volvería a tratar en 1869 en su Bosquejo histórico de la casa de Austria. La interpretación canovista, sin pretensiones metodológicas, sí supone una versión más trabajada que las editadas por aquellos años. Brevemente destacaríamos de la misma dos contribuciones. Primero, distanciándose de Colmeiro y aproximándose a Capmany, subraya la impropiedad del término decadencia por cuanto presupone una etapa anterior de dudosa prosperidad: ni antes ni después de la casa de Austria España «ha sido otra cosa que un rincón» aislado y mal comunicado de Europa, carente de una buena base natural de recursos y rodeada de naciones más ricas y pobladas. En segundo lugar, a los condicionamientos geográficos añadía Cánovas los institucionales, indudablemente asociados a la dinastía austriaca, «la luz siniestra que comenzaba a alumbrar la nación y a secar de paso su inteligencia» ${ }^{26}$.

\subsection{De la historia económica a la economía de la decadencia}

Dentro de los distintos periodos que jalonan la aclimatación de la economía como ciencia en el Ochocientos, el interés por la historia económica será más acusado en la primera mitad del siglo. Quizá tuviera que ver con tres hechos -la propia dinámica de los acontecimientos (emancipación colonial, desamortizaciones...), la difusión de la «economía industrial» de Say y la escasa profesionalización de la disciplina- que tendían a resaltar la utilidad de los ejercicios de historia económica, bien para ilustrar acerca de las sendas o vías de crecimiento seguidas por las economías industriales o, simplemente, como fuente de información auxiliar para ciencias que, como la economía, daban sus primeros pasos ${ }^{27}$.

Desde las filas de la Ilustración tardía, será Capmany quien realice una de las contribuciones más rigurosas y clarificadoras al tema de la decadencia. En 1807 encabezaba así la primera de sus Cuestiones críticas: «Si la industria, la agricultura y la población de España en los siglos pasados han llevado ventaja a las del tiempo presente». Con ella, pretendía polemizar con Caresmar y contradecir su breve trabajo titulado «Consistencia antigua y moderna de Cataluña en la que se prueba ser en lo antiguo más poblada, rica y abundante que hoy» ${ }^{28}$. A partir del análisis

\footnotetext{
${ }^{26}$ Peiró Martín (1995), Cánovas (2004, pp. 4 y 35).

27 Almenar (2000).

${ }^{28}$ Capmany (1980, pp. 4-73). Vid. P. Vilar (1973) y E. Lluch (1973, pp. 135-146).
} 
de casos -sedería de Toledo, pañería segoviana, ferias de Medina-... -y del manejo de fuentes legales, concluía que al arbitrismo, a efectos de justificar la decadencia fabril, «le era necesario ponderar la pasada prosperidad». Pero añade:

«Mientras no hallemos noticias más verídicas y circunstanciadas, tenemos derecho a dudar; el que duda no niega, sino que teme ser engañado. Prediquen y ponderen cuanto quieran la riqueza y prosperidad de los siglos pasados los que, celosos de la gloria nacional, o acaso deslumbrados por ella, no han considerado con el debido examen estos puntos de nuestra historia económica».

Representaba Capmany una excepción a la legión de economistas que, como apunta Comín (2000, p. 622), instrumentalizarán el «mal comportamiento de la economía española durante el Antiguo Régimen» para enfatizar las excelencias liberalizadoras de sus propuestas. Fue parcialmente el caso de Flórez Estrada: si, entre mediados del siglo xv y mediados del xvI, «intervalo brillantísimo», España figuraba entre las naciones «más comerciantes e industriosas» de Europa, desde 1550 se iniciaban «dos siglos de luto» causados por el «sistema errado de economía» con que se administró el imperio. El «gran rédito» amparado por el monopolio desvió capitales hacia el comercio; en tales condiciones, «ningún capitalista» apostaría por «emplear sus caudales en mejoras de agricultura ni en establecimiento de fábricas». Más prudente, Canga Argüelles insistía reiteradamente en la «falta que tiene la nación de documentos para poder formar la historia económica y conocer el origen de la decadencia». Por último, López de Peñalver volvía a la retórica ilustrada sobre la ciencia económica: aun cuando los metales preciosos «arruinaron nuestras artes», la causa del declive residía en que en aquel tiempo «eran poco conocidos los principios de la ciencia de la riqueza» ${ }^{29}$.

Desde la segunda mitad del siglo, constata Almenar (1997 y 2000, p. 47) cómo la construcción del andamiaje liberal y los primeros pasos de la industrialización daban pie a una literatura económica «explícitamente polémica, a veces circunstancial y de escasa altura analítica». El discurso economicista no acierta a colmar el vacío investigador y el trabajo de archivo; por lo mismo, se podrá seguir escuchando que la decadencia española era el mejor ejemplo «de aquellos pueblos opulentos cuyas leyes estaban en abierta contradicción con las teorías económicas» o que la España moderna era nación «muy productora fabrilmente» ${ }^{30}$. En Colmeiro (1965), el objetivo escenificado en la «Advertencia» a su Historia de la

\footnotetext{
${ }^{29}$ Citas, en Flórez Estrada (1991, pp. 90-136), Canga Argüelles (en Martínez de Mata, 1971, pp. 477-482) y López de Peñalver (1992, p. 183).

${ }^{30}$ Citas en De la Mora (1999, p. 92) y Del Valle (1842, p. 441).
} 
economía política en España, de 1863 -«poner de manifiesto las causas interiores de la decadencia»-, quedaba metodológicamente deslucido desde el momento en que aquélla se transformaba en el laboratorio desde el que la economía clásica pretendía probar que todos los males «proceden de la ignorancia de las leyes económicas», o dicho de otro modo: cuando la historia económica se volvía un subterfugio didáctico con el que se «nos enseña que el progreso de la economía es inseparable del progreso de la libertad civil».

Todo ello a pesar de que Colmeiro, adelantándose a la difusión española del historicismo alemán, había mantenido que «las verdades especulativas de la economía política se confirman con la experiencia del pasado». Pero en ese viaje al pasado no había investigación de primera mano; por ello, y aunque la real orden de 12 de octubre de 1860 otorgaba público reconocimiento a la obra, la época de los Austrias seguía siendo escenario de una «España que se consume en su propia llama». De los aspectos sectoriales de la obra llamaban la atención tres conclusiones: a) que la población española «declina en los reinados de Carlos v y Felipe II» para, a continuación, proseguir «de mejor en mejor»; b) en relación con las manufacturas, reconocía con modestia que «pocas veces nos hemos visto tan perplejos y dudosos» como al evaluar su estado en el siglo xvi: «Tanteadas nuestras fuerzas, hallamos muy difícil mediar con honra en semejante contienda»-pese a todo, no dudará en desacreditar la información proporcionada por Larruga o Capmany-; c) como era de esperar, los capítulos sobre comercio exterior resultan catárticos: «No hay en nuestra historia económica periodo alguno menos favorable a la libertad» ${ }^{31}$.

Una vez consumado el divorcio entre economía y liberalismo, Piernas Hurtado, en un lúcido análisis del mercantilismo, señalaba la incoherencia de atribuirle los males económicos de España: «Todos aquellos funestos acontecimientos se hubieran verificado de igual suerte aunque no se formulara la teoría mercantil», pues el «régimen económico» de la época de los Austrias era de «observancia general» en toda Europa ${ }^{32}$. En 1874, el mismo autor publicaba el breve ensayo Ideas y noticias económicas del Quijote, subtitulado «Ligero estudio bajo ese aspecto de la inmortal obra de Cervantes». En él, lejos de «buscar en Cervantes el economista científico, que esto sería en verdad pura quimera», se limitaba a comentar el caudal de noticias económicas esparcidas a lo largo y ancho de la obra. Al final dos son las conclusiones alcanzadas: el tino con que Cervantes se aproxima a las realidades económicas y el magistral retrato de la época en que la dinastía austriaca «hizo pagar bien caro a nuestra patria un momento de esplendor» ${ }^{33}$.

\footnotetext{
${ }^{31}$ Citas, en Colmeiro (1965), vol. I, pp. 45,50, 69 y 111, y vol. II, pp. 13, 135 y 283.

32 Piernas Hurtado (1895, pp. 67-68). Vid. Serrano Sanz (2001) y Malo Guillén (2001).

${ }^{33}$ Piernas Hurtado (1916), p. 60.
} 


\section{HACIA «EL TIEMPO DEL QUIJOTE»: ¿EL FINAL DE UN TÓPICO?}

«Bajo una atmósfera soporífera se extiende un páramo intelectual de una aridez que espanta. Vivimos en un país pobre. La pobreza económica explica nuestra anemia intelectual»

M. de Unamuno (1895)

En la medida en que la investigación histórica y económica demoraron su presencia, el terreno de la decadencia quedaba abonado para que, sobre sus cenizas historiográficas, se propagasen obviedades interpretativas de toda especie. La plúmbea publicística del 98 no agotó el manoseado filón literario del «desastre». Entre la aparición en La Época Moderna del artículo «En torno al casticismo», firmado por Unamuno en 1895, y el Cervantes y la invención del Quijote, de 1930, de Azaña, pasando por la generación de 1927, los tópicos de Castilla, el Quijote, la España del Siglo de Oro y el imperio como «rayo que no cesa» se reiteran en la imaginería de los Azorín, Ortega o Maeztu, sin que ni el mismísimo Ramón y Cajal falte, en 1905, a la cita con el tercer centenario cervantino con su Psicología de don Quijote y el quijotismo. En el páramo intelectual de aquellos años al que se refería Unamuno, no dejarán de florecer extrañas criaturas. Si en 1921 Ortega, tras sostener que «racionalismo, democratismo, mecanicismo, industrialismo y capitalismo», en tanto «principios modernos», constituían «propensiones específicas» de Francia, Gran Bretaña o Alemania «pero no de España», no tenía reparos en concluir que, «desde 1550 hasta el día, cuanto en España acontece es decadencia» (1999, p. 31). No le irá a la zaga Azaña nueve años después: «En realidad, España no ha vuelto a conocer tiempos nuevos desde la última década del siglo XVI» ${ }^{34}$.

Dos hechos parecen alimentar esta retórica huera. Por un lado, el que, como sostenía Américo Castro, faltasen en el Quijote «datos que permitan plantear la cuestión de si el autor escribía en vistas del apogeo o decadencia»; por otro, porque, como sugiriera Herr (2004, pp. 53-57), pese al positivismo, la influencia de la filosofía alemana -Nietzsche, Dilthey...- dejaba la puerta abierta a unas categorías especulativas - casticismo, vividura, genio, raza, Homo hispanus- tras las que esconder la ignorancia de lo realmente acontecido.

\subsection{De Altamira a Soldevilla: las últimas síntesis}

Una equilibrada integración entre formación positivista y compromiso ético y profesional de raíces krausistas explica en Altamira la voluntad de «restaurar el

\footnotetext{
${ }^{34}$ Azaña (1966), p. 1.110.
} 
crédito de nuestra historia» desde una metodología superadora de la historia externa o èvènementielle. En 1902, citando a Masdeu y Forner, volvía a reivindicar la necesidad de desmentir «la fabulosa historia» de España y del «fenómeno» de nuestra decadencia forjados desde las filas del hispanofobismo. Al tratar de hacerlo, no dudará en reconocer que «las verdaderas causas de la decadencia aún las ignoramos», si bien habría que "presumir que la causa fundamental de ella estuvo en el orden económico». Cuando en la Historia de España vuelva a tratar del mismo asunto, insistirá en la insuficiencia de las explicaciones del arbitrismo y en la necesidad de manejar fuentes de primera mano. Por tratarse de una obra de síntesis, lejos de incurrir en las generalizaciones habituales, la prudencia le permitía anticipaciones brillantes; así, al tratar de las manufacturas, reconociendo como «indudable» la crisis del xvır, añadía que «no fue ni tan absoluta, ni tan rápida, ni $\tan$ uniforme en todos sus productos» ${ }^{35}$.

La Historia de Altamira, libro «de mochila» de Pierre Vilar, acreedor de los elogios de Braudel, Vicens Vives o Elliot, constituirá referencia historiográfica obligada hasta que, medio siglo más tarde, la Historia social y económica de España y América, de 1957, abra paso a la influencia de la escuela de los Annales. Unos años antes, cuando, en 1952, comenzaba a ver la luz la Historia de España de Ferrán Soldevilla, el propio autor era consciente de que el volumen de información por entonces disponible y la propia profesionalización de los estudios históricos hacían imprescindible el trabajo en equipo. Los capítulos referidos a los siglos XVI y XVII van precedidos de un reconocimiento explícito a Modesto Lafuente, cuya obra, señalaba Soldevilla, pese a ser acusada de «providencialismo», fue objeto de intenso «saqueo» por los mismos historiadores que la criticaban. En el capítulo dedicado a la economía en tiempos de los Austrias se hacía eco de las últimas monografías de Kellebenz, Hamilton o Nef. Como en Altamira, la síntesis no excluye la recuperación de la vieja tesis de Capmany sobre el hipotético «renacimiento industrial» de la primera mitad del siglo XVI.

\subsection{De las historias políticas a la historia económica de la España cervantina}

«¿Significa el protestantismo norteño un peligro para la civilización cristiana? Sí, pues él fue la premisa del racionalismo, de la revolución liberal y de la revolución actual marxista-bolchevique»

Menéndez-Reigada (1939)

La ampliación incesante de la producción historiográfica sobre la economía de los siglos XVI y XVII la volverían inmanejable de no disponer de obras de síntesis

${ }^{35}$ Las citas, de Altamira (1997, pp. 123 y 126, y 2001, cap. III, pp. 1.027-1.086). Sobre Altamira, véanse Fontana (1987, pp. 415-427) y Asín (2001). 
como la elaborada por Linz, entre otros. En un balance sobre las principales monografías que, sobre el periodo que nos ocupa, se editaron entre 1928, fecha de las primeras publicaciones de Hamilton, y 1974, año en que alcanzaba su sazón aquella afloración de ensayos sobre lo que Morineau bautizaría como «la religión de la crisis» -la del siglo xviI-, Linz (1974) anotaba casi 250 títulos. En fechas recientes, P. Tedde (2002, pp. 619-660) llamaba la atención sobre las tres corrientes que habían contribuido en España a «extender el aprecio por los estudios de historia económica». La primera, procedente del neohistoricismo alemán, a través de Giner y de la Junta de Ampliación de Estudios, alcanzaba a universitarios españoles que, como Flores de Lemus o Carande, habían completado estudios en Berlín o Friburgo. El segundo estímulo, partiendo del ámbito de la historia del derecho y de las instituciones, vía Hinojosa y los Anales de Historia del Derecho, llevaba a García Valdeavellano, Rubio Sacristán, E. Ibarra, al mismo Carande y a Bermúdez Cañete.

Este último realizaba en 1924 una pormenorizada revisión de la historiografía económica española e internacional sobre la decadencia. En ella, además de elogiar las publicaciones de Haebler, Haring, Klein o Wiebe por el manejo de fuentes primarias, recordaba el abandono de la historia económica nacional, así como el carácter «político» de la literatura económica liberal sobre el tema -Pedregal, Picatoste, Colmeiro, Cánovas-. Tras referirse al sistema de empresa que los historiadores alemanes conocían como Verlagssystem, coincidía con Capmany en sostener que hablar de decadencia presuponía reconocer una prosperidad previa:

«No es lo mismo coyuntura de alza en un ciclo económico que verdadera plenitud [...]. ¿Puede hablarse de decadencia? Lo que ocurrió es que por entonces empezó a manifestarse la incapacidad de nuestra industria, cuando la economía europea dejaba de ser agrícola para convertirse en capitalista. Mientras en el mundo predominó una economía agrícola, España fue un país como los demás. España no ha decaído; en realidad, continuó su ritmo, que es tan lento $[\ldots])^{36}$

La tercera de las corrientes sugeridas por Tedde es la procedente del hispanismo -los Haring, Klein, Usher, Hamilton...-, cuya difusión quedaría parcialmente eclipsada por lo que Jover llamó la «inflación de la historiografía nacionalista». Un efecto colateral de la pretensión política de recuperar los mitos y valores del Siglo de Oro será el auge de los estudios modernistas, cuantificable a partir de las tesis doctorales leídas en estos años. Del yermo historiográfico de estos años salvaba Jover (1999, pp. 273-320), por su «determinación científica», los trabajos de Viñas Mey, Carande, Larraz y Rumeu de Armas, aparecidos en los primeros

\footnotetext{
${ }^{36}$ Bermúdez Cañete (1956), p. 251.
} 
años cuarenta. En 1944 era Rubio Sacristán quien saludaba la obra de Carande como «modelo de investigación histórica». Ese mismo año, y también a propósito de la aparición del primer volumen de la obra de Carande, aprovecha A. Ullastres la ocasión para trazar un balance sectorial de los estudios económicos disponibles sobre la España del siglo xvi. En el lado del haber destacaba Ullastres, en primer lugar, la coincidencia de Carande con Heckscher -cuya obra La época mercantilista, de 1931, se editaba en español en 1943- en mantener la improcedencia de hablar en España del mercantilismo como sistema de política económica. Pero deleitémonos con aquellas reflexiones que, para Carande (1943, p. 140), suponían el «mentís más terminante de la supremacía del factor económico en la interpretación de la historia»:

«Carlos v, ante el tormento de la penuria, perpetua como el infierno, sabía que la economía era la sierva de sus designios. Los metales preciosos irrumpían a torrentes [...] la economía española, falta de empresarios en el campo y en los talleres, falta de ahorros y de espíritu capitalista, pero, sobrada de espíritu idealista y caballeresco, no los contenía, no desplegaba fuerzas capaces de remesarlos.»

En segundo lugar, destacaba Ullastres cómo la mayor disponibilidad de fuentes permitía desentrañar una organización manufacturera dirigida por los «mercaderes-empresarios sin industria» -los «fabricantes sin fábricas» o los «mercaderes hacedores de paños», que hoy tan bien conocemos gracias a Torras y a García Sanz-. Por último, la obra de Carande permitía avances decisivos en el conocimiento de la historia fiscal y monetaria española. Pero -por motivos ajenos a la disciplina y sin que pareciera importarle incurrir en contradicciones- Ullastres parecía poner especial interés en destacar las sombras: la obra de Carande, dirá, aportaba un enfoque "predominantemente castellano» que, al abarcar un marco cronológico corto, limitaba «las posibilidades de extraer consecuencias con respecto a las leyes del desenvolvimiento económico». Finalmente, acabará por deslizar dos sonados juicios de valor: con el primero sentenciaba que, a pesar de que «posteriores investigadores sigan trabajando hasta agotar el material existente, es muy posible que nunca lleguemos a conocer la entraña viva» de lo económico; con el segundo, más ácido, lamentaba que las investigaciones de Carande no modificasen «en sus líneas generales las ideas que se tenían de la historia económica de la época» ${ }^{37}$.

El año 1943 fue pródigo en novedades editoriales. Coincidiendo con la obra de Carande y la traducción de Heckscher, veía la luz el primer volumen, dedicado

\footnotetext{
${ }^{37}$ Ullastres (1944), pp. 221-245.
} 
a los siglos XVI y XVII, de la Historia de la economía española, de J. Carrera Pujal. De la misma reclaman la atención dos afirmaciones: a) tras levantar acta del desconocimiento existente en materia de historia económica, adelantaba su compromiso metodológico - quizá mirando de reojo a la obra de Colmeiro y con pretensiones de superarla- de «acompañar la prueba documental en la exposición de los hechos y de las ideas», por cuanto en el «enjuiciamiento» de aquellos siglos se «ha pecado (de modo general) de derrotismo»; b) la historiografía ilustrada y liberal sobre la época constituía un ejercicio de «despiadada crítica». Con la literatura del arbitrismo mostraba su desacuerdo en lo referente a la pretendida prosperidad del Quinientos: «No hay razón para sostener que se anticipase Castilla a otros países mejor dispuestos para crear una industria fuerte; ni había capitalistas ni organización comercial para sostenerla» ${ }^{38}$.

La obra de Carrera Pujal no pasó desapercibida. No le harán justicia ni el prólogo de Perpiñá ni la posterior reseña que el mismo autor le dedicará en Anales de Economía. En el primero, Perpiñá sostenía que la economía castellana del siglo XVI «era una economía de consumo» sometida a un «régimen práctico de autarquía». En la reseña (1943a) aún se mostraría más tajante al sostener, desde un desconcertante materialismo histórico y ferroviario, que, «si no existe ni puede existir una historia de la economía española hasta, por lo menos, el siglo XIX», tampoco «existen ni pudieron existir economistas».

De mayor interés resultaba la reseña de la obra realizada por Sureda Carrión para Anales de Economía. En ella, y tras reconocer la dificultad que para Colmeiro y Carrera debió de suponer el reto de escribir una historia económica a dos manos, desde los hechos y desde la economía política, apuntaba dos perceptibles lagunas en la Historia de Carrera: una, relativa a la asimetría entre la acumulación de fuentes documentales y la ausencia de un esfuerzo paralelo de depuración e interpretación desde la teoría económica; la otra, referida al supuesto «desinterés» empresarial por la manufactura en un entorno proteccionista. A este respecto, apelaba Sureda (1944, p. 250) a la insuficiencia de las explicaciones puramente sociológicas: la reserva parcial del mercado no era condición suficiente si al mismo tiempo se daban mayores expectativas de rentabilidad para la inversión en otros sectores:

«Si no existía interés por las empresas industriales y el capital se encauzaba a inversiones fijas en juros y censos, tenía que ser debido a la presencia de circunstancias que desanimaran las iniciativas y no a la mera desidia.»

Mucho más crítico, Rubio Sacristán (1944, p. 67) condenaba al ostracismo la obra de Carrera, al limitar sus comentarios a la misma a una nota a pie de página

\footnotetext{
${ }^{38}$ Carrera Pujal (1943), pp. 2 y 79.
} 
en la que contraponía a la «magistral madurez en el oficio» de Carande la muy «voluminosa» Historia de Carrera, «por demás defectuosa» en el manejo de fuentes y en la que observaba un «inexplicable desconocimiento o preterición de obras esenciales».

También de 1943 data la edición de la La época del mercantilismo en Castilla, 1500-1700, de Larraz, en la que reaparecía el estilo metodológico y documental de Colmeiro y Carrera. Sin aportar fuentes nuevas, difícilmente las conclusiones podían evadir el marco de la generalización: «inferioridad de potencia industrial», «desviación de los precios», «falta de espíritu capitalista»... No faltaban acotaciones, hijas, sin duda, de las particulares circunstancias del momento en que escribía -«este estudio no pretende disminuir la grandeza espiritual de nuestra historia ni la epopeya colonizadora»- o sutilezas que cabe leer como un aviso a navegantes: «No puede haber gran nación sin una política acorde con la economía. Con Don Quijote solo no se puede mantener un dilatado imperio» ${ }^{39}$. Rubio Sacristán (1944, p. 66) relacionaba los pobres resultados alcanzados por la obra de Larraz con el «escaso valor histórico» de las fuentes utilizadas, a años luz del despliegue protagonizado por Carande. Finalmente, y refiriéndose a la escuela de Salamanca, comentaba Ullastres (1943, p. 282) que el «diferencial» de la literatura económica española respecto a la europea residía en la «subordinación de la economía a la moral: en aquellos siglos imperiales, lo único que quizá no supo (digamos mejor no pudo) ser imperial fue lo económico».

Antes de que la década de los 40 tocase a su fin, don Antonio Domínguez Ortiz, completando el análisis económico con el social e institucional, contribuía a enriquecer la comprensión de la historia económica de la España moderna. Y en 1949 entregaba Carande el segundo volumen de Carlos v y sus banqueros, en palabras de A. M. Bernal, «primer gran esbozo histórico de la economía castellana». En la selecta bibliografía de que se rodeaba la obra, Gonzalo Anes y Jordi Nadal eran citados por Carande como dos «incipientes cultivadores de la historia económica» ${ }^{40}$.

\subsection{De Annales y el materialismo histórico a la «revolución de los modernistas»}

El Congreso Internacional de Ciencias Históricas de 1950 (París) asistía a las exequias del positivismo y de la histoire événementielle, y al alumbramiento de la pretendida «historia total». En España, la sombra de Vicens Vives se alargará sobre la década. Su Manual de historia económica de España, de 1956, sobre renovadas bases econométricas y metodológicas, añadía al estudio de la economía

\footnotetext{
${ }^{39}$ Larraz (1943), pp. 70-71 y 148.

${ }^{40}$ Cfr. Fernández (2000, pp. 133-182) y Bernal (2000, p. 238).
} 
española panoramas o aproximaciones regionales y sectoriales inéditos, en parte posibles por las contribuciones previas de los Ruiz Almansa, Nadal, Giralt, Viñas Mey, Palacio Atard o Domínguez Ortiz ${ }^{41}$. Desde 1953, quien fuese estrecho colaborador de Braudel y el «mejor conocedor de la historia económica de la Castilla de los Austrias», en palabras de Fontana, contribuirá con Carande a la renovación del modernismo español. Sabiamente, García Sanz (2000, p. 320) estilizaba así esa contribución:

«Respecto a las manufacturas, el que haya leído atentamente sus trabajos, se preguntará extrañado por qué se ha tomado tan en serio, como una novedad historiográfica, eso de la «protoindustrialización» [...] También se puede afirmar que esto que se llama hoy, con estruendo expresivo, «historia del consumo u de la vida material», fue el enfoque que Felipe Ruiz trasciende en estos trabajos.»

El «siglo de Cervantes» quedaría magistralmente esbozado por la pluma de Felipe Ruiz Martín (1990, pp. 60-64) en unas pocas y juiciosas frases:

«El descubrimiento y conquista de América, representó una oportunidad singular para el capitalismo castellano [...] Pero al capitalismo castellano no le dejaron disfrutar en solitario de su suerte; temprano se vio concurrido por el capitalismo cosmopolita [...]

Lo mercantil está en boga en Castilla antes de 1566. Sólo como expediente -vehículo, no meta- intervienen en la industria los capitalistas aplicando el verlagssystem e inclusive el domesticssystem. Desde 1566 en adelante, el capitalismo desdeña las mercaderías y se vuelca sobre las finanzas.»

Pero en la década de los 50, la «monarquía» de los Annales no será absoluta. En el horizonte historiográfico de 1954, desde las páginas de Past and Present, irrumpía E. J. Hobsbawm y, con él, el largo, y en ocasiones tedioso, debate sobre la transición del feudalismo al capitalismo. Excelentemente compendiado por Fernández Albaladejo (1983), dio frescura a las lecturas que venían haciéndose de la crisis del Seiscientos. La participación en el mismo de Pierre Vilar -con ocasión de la revisión de las tesis Hamilton-Keynes sobre la génesis del capitalismo, y en diálogo con los Braudel, Labrousse o Cipolla- ofreció al hispanista la posibilidad de realizar una profunda revisión de los «clásicos» del pensamiento económico español de los siglos XVI y XVII. En 1956 Les temps du Quichotte, un regalo intelectual para los estudiosos de la «decadencia», dejaba definido el ciclo histórico

${ }^{41}$ Sobre Vicens, vid. Marichal (1995, pp. 327-331) y García Cárcel (2000, pp. 283-310). 
de 1598-1620 como «crisis decisiva» del «imperialismo español, etapa suprema del feudalismo». Será en esa crucial coyuntura cuando nuestro hidalgo espete a su fiel escudero aquello de «id a gobernar vuestra casa y a labrar vuestros pegujales, y dejaos de pretender ínsulas».

También desde la historia del pensamiento económico se producen notables avances en el análisis de las doctrinas del Siglo de Oro ${ }^{42}$. Fue el caso, entre otros, del estudio, editado en 1952, de Grice-Hutchinson sobre la Escuela de Salamanca. Poco más tarde, de la mano de los Elliot, Kamen, Lynch o Bennassar, el hispanismo adelantaba la frontera informativa del siglo de la decadencia con un conocimiento más exhaustivo de la cultura, el poder y la sociedad en la España de los Austrias. Por esas mismas fechas, una nueva generación de economistas e historiadores de la economía española -los Nadal, Anes, Bernal, Eiras, García Sanz...-, regionalizando la escala analítica, ampliando la base documental y mejorando su tratamiento, ofrecía una perspectiva sectorial y agregada más nítida de aquellos dos siglos. Ellos, y no otros, deben ser considerados como los abanderados, en su versión española, de la pomposamente llamada revolt of the early modernists ${ }^{43}$.

\section{BIBLIOGRAFÍA}

Abellán, J. L. (1989): Historia crítica del pensamiento español. Madrid: Espasa-Calpe. Almenar Palau, S. (1997): «Los primeros economistas clásicos y la industrialización», en G. Bel y A. Estruch (coords.), Industrialización en España: entusiasmos, desencantos y rechazos. Ensayos en homenaje al profesor Fabián Estapé. Madrid: Civitas, pp. 139-166.

- (2000): «El desarrollo del pensamiento económico clásico en España», en E. Fuentes Quintana (dir.), Economía y economistas españoles. 4. La economía clásica. Barcelona: Círculo de Lectores, pp. 7-92.

- (2002): «La historia del pensamiento económico: un panorama retrospectivo», en E. Fuentes Quintana (dir.), Economía y economistas españoles. 7. La consolidación académica de la economía. Barcelona: Círculo de Lectores, pp. 661-710.

Almirall, V. (1979) [1886]: Lo catalanisme. Barcelona: Ediciones 62.

Altamira (1997) [1902]: Psicología del pueblo español. Introducción de R. Asín. Madrid: Biblioteca Nueva.

— (2001) [1900-1911]: Historia de España y de la civilización española. Estudio preliminar de R. Asín. Barcelona: Crítica.

ANES, G. (1965): «Nota preliminar», en Colmeiro, Historia de la economía política en España. Madrid: Tecnos, pp. 1-44.

- (2004): «La decadencia desde el Siglo de las Luces», en J. Pérez Fernández, C. Sebastián y P. Tedde, Estudios en homenaje a Luis Ángel Rojo. Economía y cambio histórico. Madrid: Editorial Complutense, vol. 1, pp. 53-63.

\footnotetext{
${ }^{42} \mathrm{Al}$ respecto, véase Almenar (2002).

${ }^{43}$ Llopis (2004).
} 
Argemí, L. (2004): Liberalismo mercantilista: un cuasi-sistema. Madrid: Síntesis.

ARriquíBAR, N. DE (1987) [1779]: Recreación política. Reflexiones sobre el Amigo de los Hombres en su Tratado de población considerado con respecto a nuestros intereses. Ed. de J. Astigarraga y J. M. Barrenechea. Bilbao: Instituto Vasco de Estadística.

AzAÑa, M. (1966-1968) [1930]: Obras completas. México DF: Oasis, 4 vols.

BAECK, L. (1998): «Monetarismo y teorías del desarrollo en la Península Ibérica en los siglos XVI-XVII», en F. Gómez Camacho y R. Robledo (eds.), El pensamiento económico de la escuela de Salamanca. Salamanca: Universidad de Salamanca-Fundación Duques de Soria, pp. 165-205.

Bennassar, B. (1983): La España del Siglo de Oro. Barcelona: Crítica.

Bermúdez Cañete, A. (1956) [1924]: «La decadencia económica de España en el siglo xvi. Ensayo de una interpretación». Revista de Economía Política VII (1), pp. 238-256.

Bernal, A. M. (2000): «Don Ramón Carande: la proyección internacional de la historiografía española en el siglo xx», en E. Sarasa y E. Serrano (coords.), Historiadores de la España medieval y moderna. Zaragoza: Institución Fernando el CatólicoCSIC, pp. 225-242.

Campillo y Cossío, J. de (1993) [1789]: Nuevo sistema económico para América. Ed. de M. Ballesteros. Oviedo: Grupo Editorial Asturiano.

CAnga Argüelles, J. (1971) [1794]: «Nota al memorial en razón de la despoblación y riqueza de España», en Martínez de Mata, pp. 477-482.

Cánovas del Castillo, A. (2004) [1869]: Bosquejo histórico de la casa de Austria. Ed. de D. Castro Alfín. Madrid: Urgoiti Editor.

CAPMANY, A. DE (1961) [1779-1792]: Memoria histórica sobre la marina, comercio y artes de la antigua ciudad de Barcelona. Intr. de E. Giralt. Barcelona: Cámara de Comercio, Industria y Navegación, 2 vols.

- (1980) [1807]: Cuestiones críticas sobre varios puntos de historia económica, política y militar. Ed. de J. Fontana. Barcelona: Diputació de Barcelona-Alta Fulla, pp. 4-73.

CARANDE, R. (1943): Carlos v y sus banqueros (vol. I: Vida económica de Castilla, 15161556). Madrid: Revista de Occidente.

Carrera Pujal, J. (1943): Historia de la economía española. Prólogo de R. Perpiñá. Barcelona: Bosch.

Castro, A. (1980) [1925]: El pensamiento de Cervantes. Barcelona: Noguer.

CatalÁn, D. (1982): «España en su historiografía» (introducción), en R. Menéndez Pidal, Los españoles en su historia. Madrid: Espasa-Calpe.

Cervantes, M. DE (1972) [1605-1615]: Don Quijote de la Mancha (2 vols.). Ed. de J. J. Allen. Madrid: Cátedra.

CERVERA Ferri, P. (2003): El pensamiento económico de la Ilustración valenciana. Valencia: Generalitat Valenciana.

Colmeiro, M. (1965) [1863]: Historia de la economía política en España. Nota preliminar y bibliografía de G. Anes. Madrid: Tecnos.

Сомín Сомín, F. (2000): «Los economistas clásicos y los políticos liberales, ante los problemas de la economía española», en E. Fuentes Quintana (dir.), Economía y economistas españoles. 4. La economía clásica. Barcelona: Círculo de Lectores, pp. 621-703.

Costa, J. (1981) [1898]: Reconstitución y europeización de España y otros escritos. Ed. de A. Martín-Retortillo. Madrid: Instituto de Administración Local. 
Domínguez Ortiz, A. (2000): «Juros y censos en la castilla del Seiscientos: una sociedad de rentistas», en A. M. Bernal (dir.), Dinero, moneda y crédito en la monarquía hispánica. Madrid:. Fundación ICO-Marcial Pons, pp. 789-807.

Ellıot, J. H. (1973): «La decadencia de España», en C. M. Cipolla, P. Vilar et al. (eds.), La decadencia económica de los imperios. Madrid: Alianza Editorial, pp. 129-155.

- (1982): «Introspección colectiva y decadencia de España a principios del siglo XVII», en J. H. Elliot (ed.), Poder y sociedad en la España de los Austrias. Barcelona: Crítica, pp. 198-224.

FeiJoo, B. J. (1991) [1726-1739]: Teatro crítico universal. Ed. de G. Stiffoni. Madrid: Clásicos Castalia.

Fernández, R. (2000): «Antonio Domínguez Ortiz: la historia como pasión», en E. Sarasa y E. Serrano (coords.), Historiadores de la España medieval y moderna. Zaragoza: Institución Fernando el Católico-CSIC, pp. 133-182.

Fernández Albaladejo, P. (1983): «Veinticinco años de debate sobre la crisis del siglo XVII», en T. Aston (comp.), Crisis en Europa, 1560-1660. Madrid: Alianza Editorial, pp. 368-386.

Fernández Clemente, E. (2001): «Las propuestas del regeneracionismo español. Joaquín Costa», en E. Fuentes Quintana (dir.), Economía y economistas españoles. 5. Las críticas a la economía clásica. Barcelona: Círculo de Lectores, pp. 557-580.

FERnÁNDEZ DE NAVARARETE, P. (1947) [1626]: «Conservación de monarquías y discursos políticos», en Obras, BAE, tomo XXV. Madrid: Atlas.

Flórez Estrada, A. (1991) [1812]: Examen imparcial de las disensiones de la América con la España. Ed. facs. de J. M. Pérez-Prendes. Madrid: Secretaría General del Senado.

FontAnA, J. (1982): Historia: análisis del pasado y proyecto social. Barcelona: Crítica.

- (1987): «El concepto de historia y de enseñanza de la historia de Rafael Altamira», en A. Alberola (ed.), Estudios sobre Rafael Altamira. Alicante: Instituto de Estudios Juan Gil Albert, pp. 415-427.

Forner, J. P. (1973) [1788]: Discurso sobre el modo de escribir y mejorar la historia de España. Ed. y prólogo de F. López. Madrid: Labor.

GÁndara, M. A. DE LA (1988) [1759]: Apuntes sobre el bien y el mal de España. Ed. J. Macías Delgado. Madrid: Instituto de Estudios Fiscales.

Ganivet. A. (1964) [1897]: Ideario. Ed. J. García Mercadal. Madrid: Aguado Editor.

García CÁRCel, R. (2000): «Jaume Vicens Vives: vida, obra y pensamiento», en E. Sarasa y E. Serrano (coords.), Historiadores de la España medieval y moderna. Zaragoza: Institución Fernando el Católico-CSIC, pp. 283-310.

GARCía CÁRCel, R. (coord.) (2004): La construcción de las historias de España. Madrid: Fundación Carolina-Marcial Pons.

García SAnz, A. (1999): «El contexto económico del pensamiento escolástico: el florecimiento del capitalismo mercantil en la España del siglo XVI», en E. Fuentes Quintana (dir.), Economía y economistas españoles. 2. De los orígenes al mercantilismo. Barcelona: Círculo de Lectores, pp. 131-162.

- (2000): «Felipe Ruiz Martín y la historia económica de la España moderna», en E. Sarasa y E. Serrano (coords.), Historiadores de la España medieval y moderna. Zaragoza: Institución Fernando el Católico-CSIC, pp. 314-323.

Gómez CAmacho, F. (1998): Economía y filosofía moral: la formación del pensamiento económico europeo en la escolástica española. Madrid: Síntesis. 
- (1999): «El pensamiento económico de la escuela de Salamanca», en E. Fuentes Quintana (dir.), Economía y economistas españoles. 2. De los orígenes al mercantilismo. Barcelona: Círculo de Lectores, pp. 127-207.

González, M. J. (1993): «Perfil del pensamiento monetario español de los siglos xvi y XVII», Revista de Economía Aplicada 3, pp. 21-39.

Grice-Hutchinson, M. (1982): El pensamiento económico en España (1177-1740). Barcelona: Crítica.

Hamilton, E. J. (1948): «El mercantilismo español antes de 1700», en El florecimiento del capitalismo. Ensayos de historia económica. Madrid: Revista de Occidente, pp. 185-207.

HerR, R. (2004): España contemporánea. Madrid: Marcial Pons.

Jovellanos, G. M. DE (1952) [1780]: «Discurso sobre la necesidad de unir al estudio de la legislación el de nuestra historia y antigüedades», en Obras. Ed. de C. Nocedal, BAE, tomo XLVI. Madrid: Atlas.

- (2000) [1789]: «Elogio de Carlos III», en Escritos económicos. Ed. de V. Llombart. Madrid: Instituto de Estudios Fiscales, pp. 477-495.

Jover Zamora, J. M. (1984): «Carácter del nacionalismo español», en H. Juretschke (ed.), Actas del simposio sobre posibilidades y límites de una historiografía nacional. Madrid: Instituto Germano-Español de Investigación de la Goerres-Gesellschaft, pp. 358-374.

- (1994): «Auge y decadencia de España. Trayectoria de una mitología histórica en el pensamiento español», en A. R. de las Heras et al. (eds.), Sobre la realidad de España. Madrid: Universidad Carlos III-Boletín Oficial del Estado, pp. 55-82.

- (1999): «Corrientes historiográficas en la España contemporánea», en Historiadores españoles de nuestro siglo. Madrid: Real Academia de la Historia, pp. 273-320.

KagAN, R. L. (2002): «Clío y la Corona. Escribir historia en la España de los Austrias», en G. Parker y R. L. Kagan (eds.), España, Europa y el mundo atlántico. Homenaje a John Elliot. Madrid: M. Pons, pp. 110-126.

KAmEn, H. (1985): «El siglo xviI: ¿época de decadencia?», en H. Kamen, T. H. Elliot y A. Domínguez Ortiz (eds.), «La España del siglo xvII». Cuadernos de Historia 28.

- (2005): «La España histórica del Quijote», El Cultural de El Mundo 6 de enero.

LAFUENTE, M. (1877-1882): Historia general de España desde los pueblos primitivos hasta la muerte de Fernando VII. Barcelona: Montaner y Simón.

Larraz, J. (1943): La época del mercantilismo en Castilla, 1500-1700. Madrid: Aguilar.

LinZ, J. J. (1974): «Cinco siglos de historia española: cuantificación y comparación», en D. S. Landes et al. (eds.), Las dimensiones del pasado. Estudios de historia cuantitativa. Madrid: Alianza Universidad, pp. 165-195.

Llombart, V. (1988): «Estudio preliminar», en P. Rodríguez Campomanes [1762], Reflexiones sobre el comercio español a Indias. Madrid: Instituto de Estudios Fiscales, pp. IXLVII.

Llopis Agelán, E. (2004): «España, la revolución de los modernistas y el legado del Antiguo Régimen», en E. Llopis Agelán (ed.), El legado económico del Antiguo Régimen. Barcelona: Crítica, pp. 10-76.

Lluch, E. (1973): «Antoni de Capmany: l'economia com a historia», en El pensament economic a Catalunya (1760-1840). Barcelona: Ediciones 62, pp. 135-146.

López de PeÑalver, J. L. (1992) [1792-1823]: Escritos. Ed. de E. Lluch. Madrid: Instituto de Estudios Fiscales. 
LÓPEZ-Vera, E. (2004): «De Numancia a Zaragoza. La construcción del pasado nacional en las historias de España del Ochocientos», en R. García Cárcel (coord.): La construcción de las historias de España. Madrid: Fundación Carolina - Marcial Pons, pp. 195-295.

MalladA, L. (1989) [1890]: Los males de la patria. Ed. de J. Esteban. Madrid: Fundación Banco Exterior de España.

Malo GuilléN, J. L. (2001): «El pensamiento económico del krausismo español», en E. Fuentes Quintana (dir.), Economía y economistas españoles. 5. Las críticas a la economía clásica. Barcelona: Círculo de Lectores, pp. 389-450.

Maravall, J. A. (1976): Utopía y contrautopía en el Quijote. Santiago de Compostela: Pico Sacro.

- (1984): «La crisis económica del siglo XVII interpretada por los escritores de la época», en Estudios de historia del pensamiento español. Serie tercera. El siglo del Barroco. Madrid: Cultura Hispánica, pp. 151-196.

- (1991) [1972]: «Mentalidad burguesa e idea de la historia en el siglo XvIII», en Estudios de historia del pensamiento español. Siglo XVIII. Madrid: Mondadori, pp. 250-280.

Marcos Marín, A. (2000): España en los siglos XVI, XVII y XVIII. Economía y sociedad. Barcelona: Caja Duero-Crítica.

Marichal, J. (1995): El secreto de España. Ensayos de historia intelectual y política. Madrid: Taurus.

Martín RodríGuez, M. (1999): «Subdesarrollo y desarrollo económico en el mercantilismo español», en E. Fuentes Quintana (dir.), Economía y economistas españoles. 2 .De los orígenes al mercantilismo. Barcelona: Círculo de Lectores, pp. 359-402.

Martínez de Mata, F. (1971) [1640-1650]: Memoriales y discursos. Ed. de Gonzalo Anes. Madrid: Moneda y Crédito.

Masdeu, J. F. (1982) [1783-1805]: Historia crítica de España y de la cultura española, en D. Catalán (1982).

Mateo del Peral, D. (1977): «El tratado De monetae mutatione del padre Juan de Mariana», en A. Otazu (ed.), Dinero y crédito (siglos XVI a XIX). (Actas del I Coloquio Internacional de Historia Económica). Madrid: Moneda y Crédito.

Menéndez Reigada (1939): Catecismo patriótico español. Barcelona: Península.

Menéndez y Pelayo, M. (1987) [1880-1882]: Historia de los heterodoxos españoles. Madrid: Biblioteca de Autores Cristianos.

Mercado, T. DE (1977) [1571]: Suma de tratos y contratos (2 vols.). Ed. de N. SánchezAlbornoz. Madrid: Instituto de Estudios Fiscales.

Mestre, A. (1970): Historia, fueros y actitudes políticas. Mayans y la historiografía del siglo XVIII. Jávea: Publicaciones del Ayuntamiento de Oliva.

MoncADA, S. DE (1974) [1616]: Restauración política de España. Ed. y prólogo de J. Vilar. Madrid: Instituto de Estudios Fiscales.

Mora, J. J. DE LA (1999) [1843]: De la libertad de comercio. Ed. de P. Schwartz Girón. Madrid: Instituto de Estudios Fiscales.

NADAL, J. (2001): España en su cenit. Un ensayo de interpretación. Barcelona: Crítica.

OCAMPO SuÁrez-VALDÉs, J. (2002): «Industrialización antes de la Revolución Industrial: la visión de los ilustrados», en Cuadernos de Estudios del Siglo XVIII 12-13, pp. 93-115.

ORTEGA y GASSET, J. (1999) [1921]: España invertebrada. Bosquejo de algunos pensamientos históricos. Cáceres: Universidad de Extremadura. 
— (1984) [1916]: Meditaciones del Quijote. Madrid: Cátedra.

Peiró Martín, E. (1995): Los guardianes de la historia. La historiografía académica de la Restauración. Zaragoza: Institución Fernando el Católico.

Perdices de Blas, L. (1996): La economía política de la decadencia de Castilla en el siglo XVII. Madrid: Síntesis.

- (1997): «La restauración de la riqueza de España por la industria. Reflexiones sobre el industrialismo de los arbitristas del siglo XVII», en G. Bel y A. Estruch (coords.), Industrialización en España: entusiasmos, desencantos y rechazos. Ensayos en homenaje al profesor Fabián Estapé. Madrid: Civitas, pp. 31-60.

- (1999): «El florecimiento de la economía aplicada en España: arbitristas y proyectistas», en E. Fuentes Quintana (dir.), Economía y economistas españoles. 2. De los orígenes al mercantilismo. Barcelona: Círculo de Lectores, pp. 451-498.

- (2003): «Los orígenes de la economía cuantitativa en España. La aritmética política», en L. Perdices de Blas y J. Reeder, Diccionario de pensamiento económico en España (1500-2000). Madrid: Fundación ICO-Síntesis, pp. 352-358.

Perdices de Blas, L. y Reeder, J. (1997): El mercantilismo: política económica y Estado. Madrid: Síntesis.

Pereña, L. (1998): «La escuela de Salamanca: notas de su identidad», en F. Gómez Camacho y R. Robledo (eds.), El pensamiento económico de la escuela de Salamanca. Salamanca: Universidad de Salamanca - Fundación Duques de Soria, pp. 43-65.

Perpiñá I Grau, R. (1943a): «Ante nuestra historia económica». Anales de Economía III (10), pp. 103-128.

- (1943b): «Prólogo», en J. Carrera Pujal, Historia de la economía española. Barcelona: Bosch., pp. ix-lxiii.

Perrotta, C. (1993): «Early Spanish Mercantilism. The First Analysis of Underdevelopment», en L. Magnusson (ed.), Mercantilist Economics. Massachusetts: Kluwer Academic Publishers, pp. 17-58.

Piernas HuRTADo (1895): Introducción al estudio de la ciencia económica. Madrid: Librería V. Suárez.

- (1916) [1874]: Ideas y noticias económicas del Quijote. Ligero estudio bajo este aspecto de la inmortal obra de Cervantes. Madrid: Tip. Hijos de Tello.

Rodríguez Campomanes, P. (1775): Apéndice a la educación popular. Parte segunda. Madrid: Imp. A. de Sancha.

- (1975) [1774-1775]: Discurso sobre la educación popular de los artesanos y su fomento. Ed. de J. Reeder. Madrid: Instituto de Estudios Fiscales.

— (1975) [1774-1775]: Discurso sobre el fomento de la industria popular. Ed. de J. Reeder. Madrid: Instituto de Estudios Fiscales.

Romá i Rossell, F. (1989) [1768]: Las señales de la felicidad de España y medios de hacerlas eficaces. Ed. de E. Lluch. Barcelona: Diputació de Barcelona-Alta Fulla.

Rothbard, M. R. (1999): Historia del pensamiento económico I. El pensamiento económico hasta A. Smith. Madrid: Unión Editorial.

Rubio SACRistán, J. A. (1944): «La España imperial de Carlos v y su economía». Moneda y Crédito 9, pp. 60-69.

Ruiz MarTín, F. (1990) [1965]: Pequeño capitalismo, gran capitalismo. Simón Ruiz y sus negocios en Florencia. Barcelona: Crítica. 
SAAVEdRa FAJARdo, D. (1947) [1640]: «Idea de un príncipe político-cristiano representado en cien empresas», en Obras, BAE, tomo XXV. Madrid: Atlas.

SAinz RodríGuez, P. (1924): La evolución de las ideas sobre la decadencia española. Madrid: Atlántida.

Schumpeter, J. A. (1954): Historia del análisis económico. Barcelona: Ariel.

SERRANo SANZ, J. M. (2001): «Escuelas e ideas en la Restauración decimonónica», en E. Fuentes Quintana (dir.), Economía y economistas españoles. 5. Las críticas a la economía clásica. Barcelona: Círculo de Lectores, pp. 129-150.

Soldevilla, F. (1995) [1952-1959]: Historia de España. Prólogo de F. Tomás y Valiente. Barcelona: Crítica.

Sureda Carrión, J. L. (1944): «Libros. J. Carrera Pujal: Historia de la economía española», Anales de Economía IV (14), pp. 247-254.

- (1949): La hacienda castellana y los economistas del siglo XVII. Madrid: CSIC - Instituto de Economía «Sancho de Moncada».

- (1999): «La Hacienda castellana en la literatura económica del siglo XVII», en E. Fuentes Quintana (dir.), Economía y economistas españoles. 2. De los orígenes al mercantilismo. Barcelona: Círculo de Lectores, pp.523-544.

TEDDE DE LoRCA, P. (2002): «La incorporación de la historia económica a los estudios universitarios», en E. Fuentes Quintana (dir.), Economía y economistas españoles. 7. La consolidación académica de la economía. Barcelona: Círculo de Lectores, pp. 619-660.

TuÑón DE LARA, M. (1973): Medio siglo de cultura española (1885-1936). Madrid: Tecnos.

Ullastres, A. (1943): «Historia e historiografía económicas en España (comentario a las tesis de J. Larraz)». Anales de Economía III (11), pp. 257-283.

- (1944): «Sobre España y su economía en el siglo xvI». Anales de Economía IV (14), pp. 221-245.

UlLoA, B. (1992) [1740]: Restablecimiento de las fábricas y comercio español. Ed. de G. Anes. Madrid: Instituto de Estudios Fiscales.

Unamuno, M. DE (2001) [1895]: En torno al casticismo. Madrid: Alianza.

UzTÁRIz, G. DE (1968) [1724]: Theórica y práctica de comercio y de marina. Ed. de G. Franco. Madrid: Aguilar.

VAlle, E. M. DEL (1842): Curso de economía política. Madrid: Imp. del Colegio Nacional.

Velarde Fuertes, J. (1961): Sobre la decadencia económica de España. Madrid: Tecnos.

VILAR, J. (1974): «Conciencia nacional y conciencia económica» (estudio preliminar), en Moncada [1616], Restauración política de España. Madrid: Instituto de Estudios Fiscales, pp. 5-81.

- (1999): «Sancho de Moncada, economista», en E. Fuentes Quintana (dir.), Economía y economistas españoles. 2. De los orígenes al mercantilismo. Barcelona: Círculo de Lectores, pp. 545-580.

VILAR, P. (1969): Oro y moneda en la historia (1450-1920). Barcelona: Ariel.

- (1973) [1933]: «L'obra de Capmany, model de mètode històric. La historia catalana al segle XVIII», en Assaigs sobre la Catalunya del segle XVIII. Barcelona: Curial.

- (1974): «Los primitivos españoles del pensamiento económico: cuantitativismo y bullonismo», en Crecimiento y desarrollo. Barcelona: Ariel, pp. 135-162.

Vilar Berrogaín, J. (1973): Literatura y economía. La figura satírica del arbitrista en el Siglo de Oro. Madrid: Revista de Occidente. 
Yun Casalilla, B. (2002): «El siglo de la hegemonía castellana, 1450-1590», en F. Comín, M. Hernández y E. Llopis (eds.), Historia de España (siglos $X$-XX). Barcelona: Crítica, pp. 51-84.

- (2004): Marte contra Minerva. El precio del imperio español, c. 1450-1600. Barcelona: Crítica. 